\title{
Predictive Role of Monocyte to High-density Lipoprotein Ratio for Plaque Morphology in Asymptomatic Intermediate Carotid Stenosis
}

\author{
Asemptomatik Orta Düzey Karotis Darlığında Plak Morfolojisi için \\ Monosit/Yüksek Yoğunluklu Lipoprotein Kolesterol Oranının Öngörücü \\ Rolü
}

\section{(D) Erdem Karaçöp, (D) Asım Enhoş}

Bezmialem Vakıf University Faculty of Medicine, Department of Cardiology, İstanbul, Turkey

\section{Abstract}

Objective: Carotid plaques are divided into calcified, mixed and fatty types according to the morphological ultrastructure. Increased risk of rupture, thromboembolism and stroke are more pronounced in mixed and fatty carotid plaques due to composition and instability.

The present study aimed to assess the role of monocyte to high-density lipoprotein cholesterol (HDL-C) ratio (MHR) to predict mixed and fatty plaques in patients with intermediate carotid artery stenosis.

Method: A total of 223 asymptomatic patients who had $50-70 \%$ stenosis in the carotid artery were included in this retrospective cohort study. Patients were assigned into three groups based on plaque morphology: 94 with calcified, 71 with mixed and 58 with fatty plaques. Groups were compared in terms of MHR. Predictive role of MHR for mixed and fatty plaque was investigated.

Results: MHR was significantly higher in the mixed and fatty plaque groups (16.951 \pm 5.935 vs $20.181 \pm 9.405$ vs $11.200 \pm 4.126, p<0.001)$. It, with a cut off of 13.61 , had $71.8 \%$ sensitivity and $56.6 \%$ specificity for the prediction of mixed plaque [area under the curve (AUC): $0.645,95 \%$ confidence interval $(\mathrm{Cl}): 0.571-0.718, p=0.001]$. Moreover, $\mathrm{MHR}$, with a cut off of 14.40 , had $77.6 \%$ sensitivity and $62.4 \%$ specificity for the prediction of fatty plaque (AUC: $0.746,95 \% \mathrm{Cl}: 0.675-0.818, p<0.001$ ). Multivariate regression analysis showed MHR was a significant independent predictor of mixed [odds ratio (OR): 1.230, $p<0.001$ ] and fatty (OR: 1.364, $p<0.001$ ) plaques in intermediate carotid artery stenosis, after adjusting for other risk factors.

Conclusion: MHR plays a favorable role for the prediction of mixed and fatty plaques in asymptomatic intermediate carotid artery stenosis.

Keywords: Carotid artery, monocyte to high-density lipoprotein ratio, plaque morphology

\section{Öz}

Amaç: Karotis plakları morfolojik alt yapıya göre kalsifik, mikst ve yağlı tiplere ayrılır. Mikst ve yağlı karotis plaklarının bileşimi ve kararsızlığı nedeniyle artmış rüptür, tromboembolizm ve inme riski daha belirgindir. $\mathrm{Bu}$ çalışma, orta düzey karotis arter darlığı olan hastalarda monosit/ yüksek yoğunluklu lipoprotein kolesterol (HDL-C) oranının (MHR) mikst ve yağlı plakları öngörmedeki rolünü değerlendirmeyi amaçlamıştır.

Yöntem: Bu retrospektif kohort çalışmaya karotis arterde \%50-70 stenozu olan toplam 223 asemptomatik hasta alındı. Hastalar plak morfolojisine göre üç gruba ayrıldı: 94 kalsifik, 71 mikst ve 58 yağlı plak olanlar. Gruplar MHR açısından karşılaştııılı. MHR'nin mikst ve yağlı plak için öngörücü rolü araştırıldı.

Bulgular: Mikst ve yağlı plak grubunda MHR anlamlı olarak daha

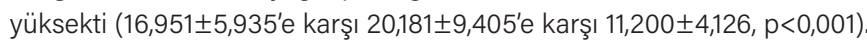
Mikst plak tahmini için 13,61 cut-off değerinin üzerinde, \%71,8 duyarlıığa ve \%56,6 özgüllüğe sahipti [Eğrinin altındaki alan (EAA): 0,645, \%95 güven aralığı (GA): 0,571-0,718, $p=0,001]$. Ayrıca $M H R$, yağlı plak tahmini için 14,40 cut-off değerinin üzerinde, $\% 77,6$ duyarlıığa ve $\% 62,4$ özgüllüğe sahipti (EAA: 0,746, \%95 GA: 0,675-0,818, p<0,001). Çok değişkenli regresyon analizinde; diğer risk faktörleri ayarlandıktan sonra, orta düzey karotis arter darlığında, MHR'nin hem mikst [olasılık oranı (OO): 1,230, $p<0,001)$ hem de yağlı $(O O: 1,364, p<0,001)$ plakların anlamlı bağımsız prediktörü olduğu bulunmuştur.

Sonuç: MHR, asemptomatik orta düzey karotis arter stenozunda mikst ve yağlı plakların öngörülmesinde olumlu bir rol oynamaktadır.

Anahtar kelimeler: Karotis arter, monosit/yüksek yoğunluklu lipoprotein oranı, plak morfolojisi

Address for Correspondence: Asım Enhoş, Bezmialem Vakıf University Faculty of Medicine, Department of Cardiology, İstanbul, Turkey E-mail: asimenhos@hotmail.com ORCID: orcid.org/0000-0002-7479-7783 Received: 19.06.2020 Accepted: 07.07.2020

Cite this article as: Karaçöp E, Enhoş A. Predictive Role of Monocyte to High-density Lipoprotein Ratio for Plaque Morphology in Asymptomatic Intermediate Carotid Stenosis. Bagcilar Med Bull 2020;5(3):75-81

๑) Copyright 2020 by the Health Sciences University Turkey, Bagcilar Training and Research Hospital Bagcilar Medical Bulletin published by Galenos Publishing House. 


\section{Introduction}

Atherosclerosis is identified as a major cause up to $20-30 \%$ of all ischemic strokes in the world (1). The pathogenesis is multifactorial involving inflammation and immune mechanisms (2). Rupture of atherosclerotic plaque causes the activation of coagulation, aggregation of platelets and thrombus formation. Composition should be taken into consideration rather than stenosis severity while interpreting vulnerable plaque (3). Plaques that constitute high triglyceride and low density lipoprotein (LDL) have higher tendency to rupture.

Monocytes are key players of innate immunity. They release proinflammatory cytokines in all stages of inflammation $(4,5)$. Atherosclerotic process from the onset to rupture is mediated by these cytokines $(6,7)$. Monocytes ingest lipoprotein and convert to foam cells. Subsequently, they become main cellular component of atherosclerotic plaque.

Monocyte has a proinflammatory effect, while high-density lipoprotein (HDL) acts as an anti-inflammatory molecule that antagonizes this effect. HDL alleviates the deleterious effect of monocytes by reversing cholesterol transport in the plaque $(8,9)$. Therefore, monocyte/HDL-cholesterol ratio (MHR) is a novel parameter used to evaluate the inflammatory condition. MHR is strikingly high among patients with cardiovascular diseases (10) and stroke (11). Additionally, it plays a strong predictive role for the prognosis after stroke (11).

Carotid plaques are divided into calcified, mixed and fatty types based on morphology detected by computed tomography angiography (CTA) (12). Mixed and fatty plaques have thin fibrous cap and high lipid content. They are unstable and easily ruptured causing transient ischemic attack and stroke (13).

Severity of stenosis and symptoms are two main factors that determine the risk of stroke in carotid artery (14). According to current guidelines (15), two situations requiring intervention are as follows: 1 ) Symptomatic patients with at least 50\% carotid artery stenosis, 2) Asymptomatic patients with at least $70 \%$ carotid artery stenosis. There is a gray zone including asymptomatic patients with intermediate (50-70\%) carotid artery stenosis. Identification of high risk individuals with intermediate carotid artery stenosis for developing symptoms is crucial. It may be beneficial to construct algorithms by adding MHR and plaque morphology to predict absolute risk. The relationship between these parameters remains to be elucidated. Hence, we hypothesize that MHR plays a strong role for the prediction of mixed and fatty plaques in asymptomatic intermediate carotid stenosis. The present study compares fatty, mixed and calcified plaques that cause asymptomatic intermediate carotid artery stenosis with respect to MHR.

\section{Materials and Methods}

\section{Study Population}

We retrospectively reviewed the medical records of 305 patients, who were admitted to the cardiology outpatient clinic with a 50-70\% stenosis in the carotid artery between 2013 and 2015. Patients with any of the followings were excluded: ischemic or non-ischemic stroke, Acute Coronary syndrome, previous cardiac surgery, known coronary artery disease, atrial fibrillation, concomitant severe valvular disease, heart failure, cardiomyopathy, congenital heart defects, renal or hepatic disease, hematological disorders, malignancy and acute or chronic inflammatory disorders. Finally, 223 consecutive patients with asymptomatic intermediate carotid stenosis were enrolled in the study. Patients were divided into three groups as follows: 1) Ninety-four patients with calcified plaque, 2) Seventy-one patients with mixed plaque, 3) Fifty-eight patients with fatty plaque. Carotid stenosis and morphology were evaluated through CTA in each patient. Evaluation of each patient was performed by a multidisciplinary team including radiologist, neurologist, cardiologist and cardiothoracic surgeon. Local ethics comitte approved the study with the number 3.841 on 06.03.2020. Declaration of Helsinki were taking into consideration while conducting the study.

\section{Statistical Analysis}

Mean \pm standard deviation were used to assess continuous variables and number and percentages were used to assess categorical variables. Test of normality was performed either Shapiro-Wilk test or Kolmogorov-Smirnov test. Student t-test was the test of choice to investigate differences between continuous variables with normal distribution. If the distribution was not normal for continuous variables, Mann-Whitney U test were performed. Chi-square test was used to assess difference between categorical variables. Sensitivity and specificity analysis were conducted with the receiver-operating characteristics (ROC) curve. Additionally, variables that had predictive value for mixed and fatty plaques in univariate analysis were integrated into multivariate logistic regression to determine statistical significance. A two sided p-value which was smaller than 0.05 , was considered statistically significant. 


\section{Results}

Baseline demographical characteristics and clinical, laboratory data of 223 patients (94 calcified, 71 mixed, 58 fatty) were summarized in Table 1. Fatty plaque group were younger $(64.98 \pm 7.812$ vs $71.31 \pm 10.683$ vs $72.63 \pm 8.257$, $\mathrm{p}<0.001$ ) and smoking (41.4 vs 23.9 vs $20.2 \%, \mathrm{p}=0.013$ ) was more cammon among this group. Additionally white blood cell count $\left(8.899 \pm 2.567\right.$ vs $8.362 \pm 1.959$ vs $7.314 \pm 1.667 \times 10^{3} / \mathrm{L}$, $\mathrm{p}<0.001)$, neutrophil count $(5.861 \pm 2.164$ vs $5.139 \pm 1.857$ vs $\left.3.938 \pm 1.241 \times 10^{3} / \mathrm{L}, \quad \mathrm{p}<0.001\right)$ and monocyte count ( $0.725 \pm 0.230$ vs $0.685 \pm 0.168$ vs $0.552 \pm 0.177 \times 10^{3} / \mathrm{L}, \mathrm{p}<0.001$ ) were higher in fatty plaque group.
Total cholesterol $(188.36 \pm 42.791$ vs $198.06 \pm 43.089$ vs $211.71 \pm 40.230 \mathrm{mg} / \mathrm{dL}, \mathrm{p}=0.003)$ and LDL $(116.97 \pm 34.816$ vs $120.89 \pm 33.450$ vs $130.05 \pm 31.044 \mathrm{mg} / \mathrm{dL}, \mathrm{p}=0.041$ ) were lower in fatty plaque group due to more statin usage (25.9\%). HDL ( $38.52 \pm 8.923$ vs $42.77 \pm 10.469$ vs $49.94 \pm 7.377$ $\mathrm{mg} / \mathrm{dL}, \mathrm{p}<0.001$ ) was significantly lower in fatty plaque group, respectively.

There was no difference in terms of antiaggregant and statin usage between three groups (Table 2). Few patients were taking acetylsalicylic acid ( 36.2 vs 28.2 vs $24.5 \%$, p=0.300) and clopidogrel (5.2 vs 7 vs $7.4 \%, p=0.857$ ) in each group.

\section{Table 1. Patient characteristics by carotid plaque morphology}

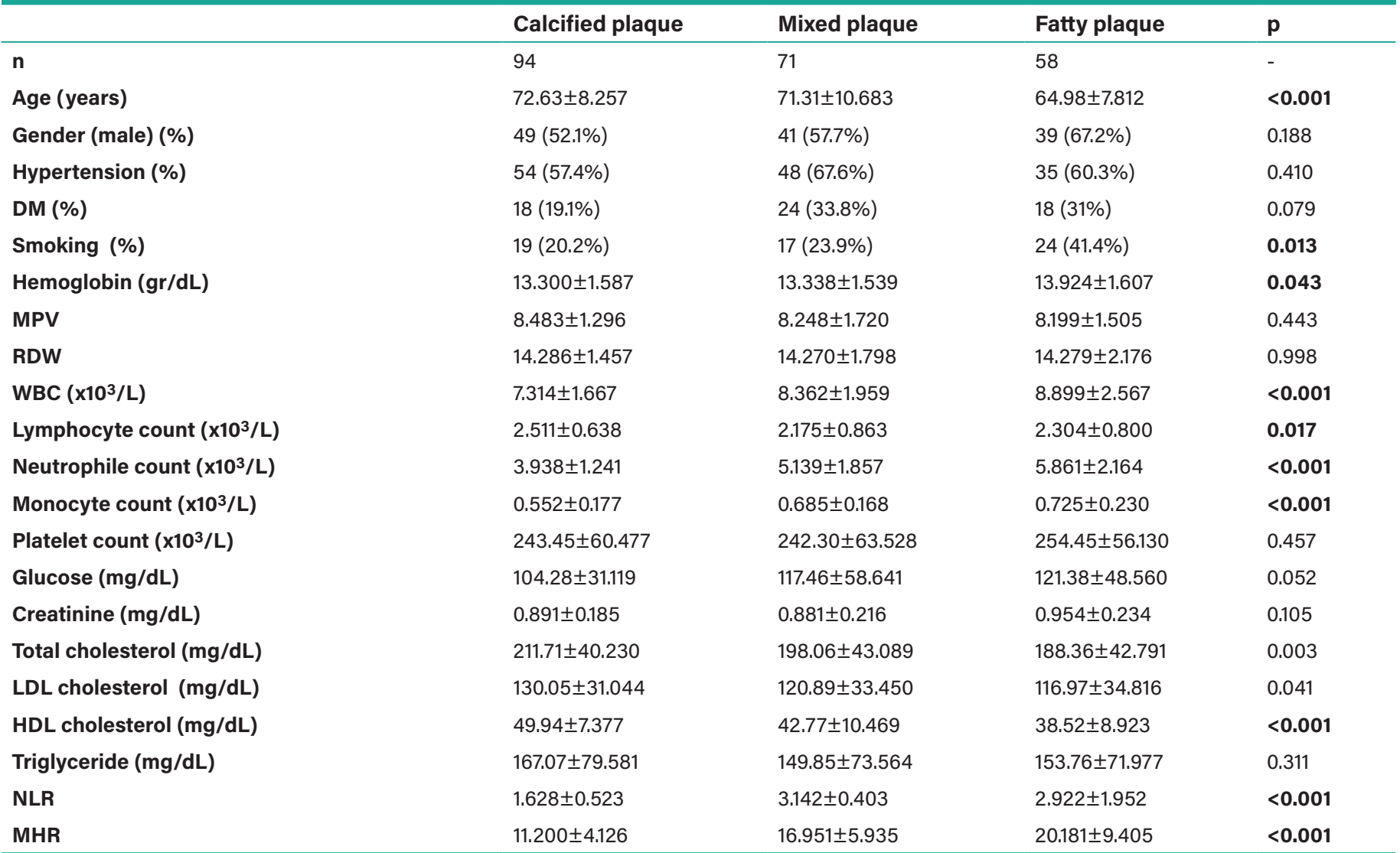

Data is presented as means \pm SD or $n(\%)$, SD: Standard deviation, DM: Diabetes Mellitus, HDL: High density lipoprotein, LDL: Low density lipoprotein, MHR: Monocyte count/HDL cholesterol ratio, MPV: Mean platelet volume, NLR: Neutrophil count/lymphocyte ratio, PDW: Platelet distribution width, RDW: Red cell distribution width, WBC: White blood cell

Table 2. Medications taken by patients

\begin{tabular}{lllll} 
& Calcified plaque & Mixed plaque & Fatty plaque & p \\
\hline $\mathbf{n}$ & 94 & 71 & 58 & - \\
ASA (\%) & $23(24.5 \%)$ & $20(28.2 \%)$ & $21(36.2 \%)$ & 0.300 \\
Clopidogrel (\%) & $7(7.4 \%)$ & $5(7 \%)$ & $1(1.2 \%)$ & 0.857 \\
ASA + Clopidogrel (\%) & $2(2.1 \%)$ & $3(4.2 \%)$ & $15(25.9 \%)$ & 0.622 \\
Statin (\%) & $18(19.8 \%)$ & $19(26.8 \%)$ & 0.454 \\
\hline
\end{tabular}

Data is presented as n (\%), ASA: Acetylsalicylic acid 
Monocyte to high-density lipoprotein cholesterol ratio was found to be higher in fatty and mixed groups $(20.181 \pm 9.405$ vs $16.951 \pm 5.935$ vs $11.200 \pm 4.126, \mathrm{p}<0.001)$. Sensitivity and specificity analysis were conducted with the ROC curve and the respective areas under the curve (AUCs) were used to investigate the predictive value of MHR for prediction of mixed and fatty plaques (Figures 1,2). MHR had 71.8\% sensitivity and $56.6 \%$ specificity for prediction of mixed plaque [AUC: $0.645,95 \%$ confidence interval (CI): 0.571-
0.718, $\mathrm{p}=0.001]$. Moreover MHR had $77.6 \%$ sensitivity and $62.4 \%$ specificity for prediction of fatty plaque (AUC: 0.746 , 95\% CI: 0.675-0.818, p<0.001).

Multivariate regression analysis showed MHR was a significant independent predictor of both mixed [odds ratio (OR): 1.230, $\mathrm{p}<0.001$ ] and fatty (OR: 1.364, $\mathrm{p}<0.001$ ) plaques in asymptomatic patients with intermediate carotid artery stenosis, after adjusting for other risk factors (Table 3,4).

Table 3. Univariate and multivariate regression analyses of the predictors of mixed carotid plaque morphology

\begin{tabular}{|c|c|c|c|c|}
\hline Variables & Univariate analysis & & Multivariate analysis & \\
\hline & Odds ratio $(95 \% \mathrm{CI})$ & $\mathbf{p}$ & Odds ratio $(95 \% \mathrm{Cl})$ & $\mathbf{p}$ \\
\hline Age (years) & $0.983(0.948-1.018)$ & 0.336 & - & - \\
\hline Gender (male) & $1.255(0.675-2.335)$ & 0.473 & - & - \\
\hline Hypertension (\%) & $1.546(0.812-2.942)$ & 0.185 & - & - \\
\hline DM (\%) & $2.156(1.059-4.390)$ & 0.034 & $1.117(0.358-3.487)$ & 0.848 \\
\hline Smoking (\%) & $1.243(0.592-2.610)$ & 0.566 & - & - \\
\hline Hemoglobin (gr/dL) & $1.016(0.836-1.234)$ & 0.876 & - & - \\
\hline WBC $\left(\times 10^{3} / L\right)$ & $1.324(1.120-1.564)$ & 0.001 & $1.736(0.776-3.881)$ & 0.179 \\
\hline Lymphocyte count ( $\left.\times 10^{3} / L\right)$ & $0.552(0.361-0.845)$ & 0.006 & $1.534(0.238-9.890)$ & 0.653 \\
\hline Neutrophile count $\left(\times 10^{3} / \mathrm{L}\right)$ & $1.716(1.358-2.170)$ & $<0.001$ & $0.295(0.093-0.937)$ & 0.038 \\
\hline Platelet count $\left(\times 10^{3} / L\right)$ & $1.000(0.994-1.005)$ & 0.902 & - & - \\
\hline Glucose (mg/dL) & $1.008(1.000-1.016)$ & 0.053 & $1.005(0.994-1.017)$ & 0.350 \\
\hline Creatinine (mg/dL) & $0.793(0.167-3.759)$ & 0.770 & - & - \\
\hline Total cholesterol (mg/dL) & $0.992(0.985-1.000)$ & 0.044 & $1.000(0.990-1.009)$ & 0.925 \\
\hline NLR & $4.158(2.527-6.839)$ & $<0.001$ & $11.883(1.656-85.249)$ & 0.014 \\
\hline MHR & $1.267(1.171-1.370)$ & $<0.001$ & $1.230(1.124-1.346)$ & $<0.001$ \\
\hline
\end{tabular}

DM: Diabetes Mellitus, MHR: Monocyte count/HDL cholesterol ratio, NLR: Neutrophil count/lymphocyte ratio, WBC: White blood cell, Cl: Confidence interval

Table 4. Univariate and multivariate regression analyses of the predictors of fatty carotid plaque morphology

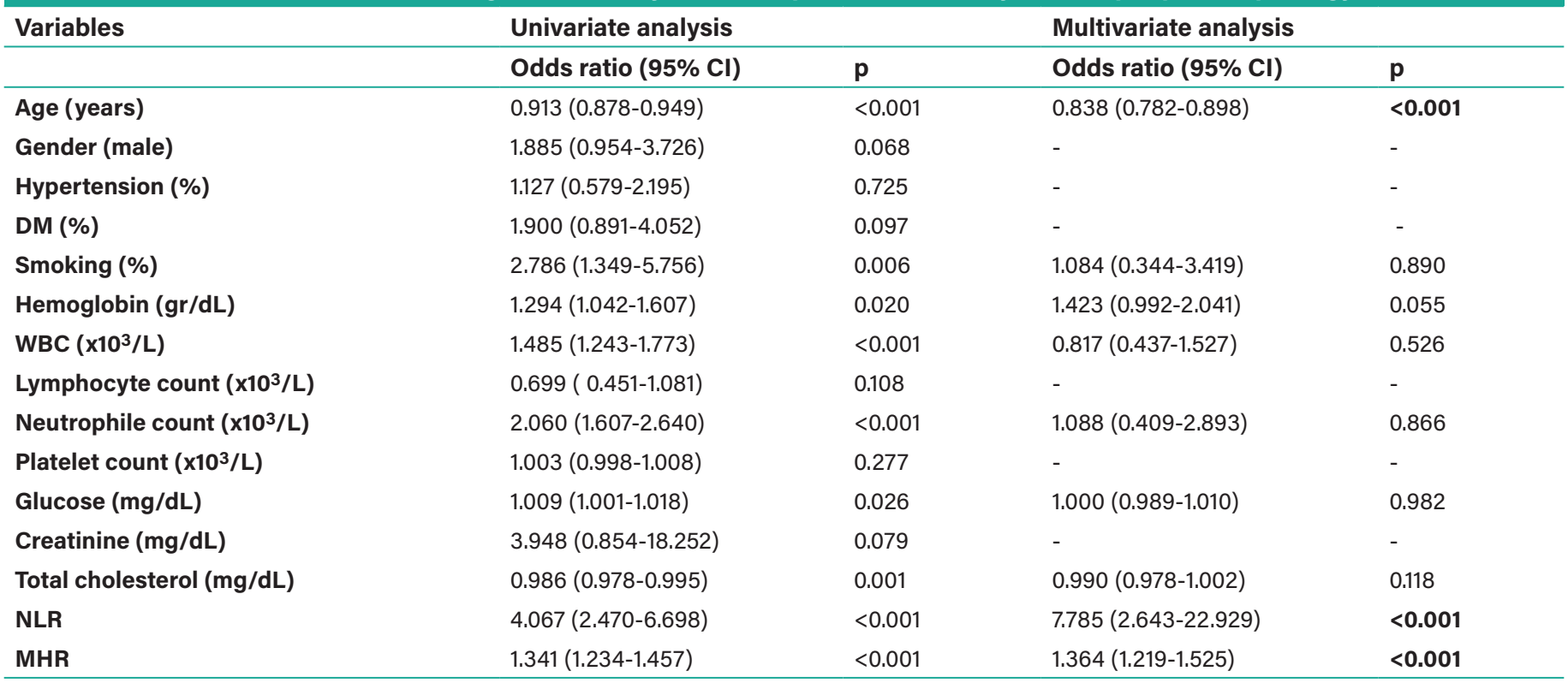

DM: Diabetes Mellitus, MHR: Monocyte count/HDL cholesterol ratio, NLR: Neutrophil count/lymphocyte ratio, WBC: White blood cell, Cl: Confidence interval 


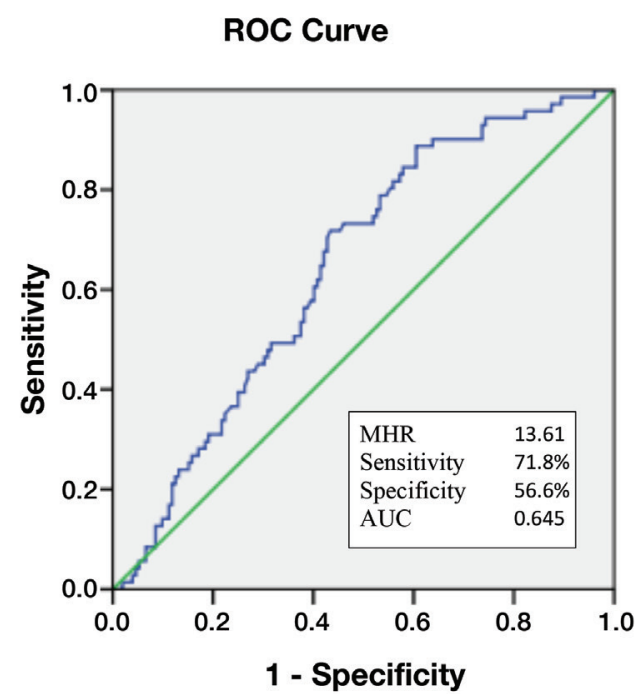

Diagonal segments are produced by ties.

Figure 1. A monocyte/high density lipoprotein ratio (MHR) cut off of 13.61 predicts mixed carotid plaque morphology in patients with $50-70 \%$ stenosis of the carotid artery, with a sensitivity of $71.8 \%$ and a specificity of $56.6 \%$

ROC: Receiver operating characteristic, AUC: Area under the curve

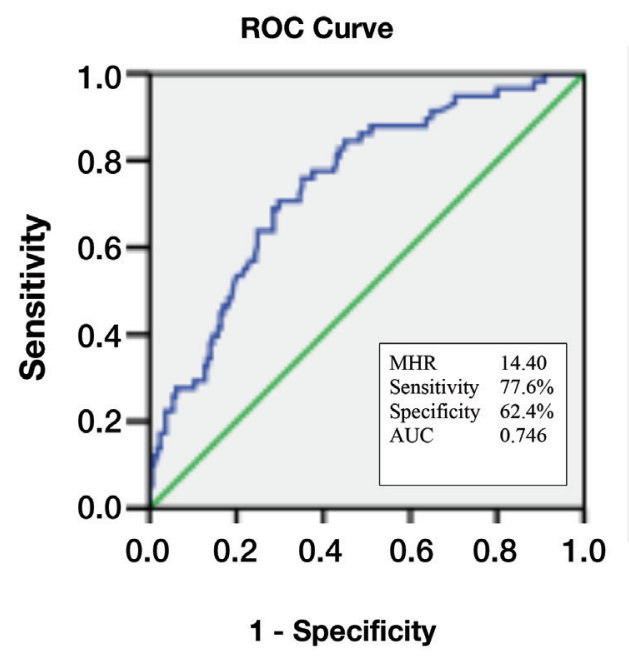

Diagonal segments are produced by ties.

Figure 2. A monocyte/high density lipoprotein ratio (MHR) cutoff of 14.40 predicts fatty carotid plaque morphology in patients with $50-70 \%$ stenosis of the carotid artery, with a sensitivity of $77.6 \%$ and a specificity of $62.4 \%$

ROC: Receiver operating characteristic, AUC: Area under the curve

\section{Discussion}

The main findings of the study were as follows: 1) A raised MHR was found to be significantly higher in asymptomatic
50-70\% carotid artery stenosis with mixed and fatty plaques, 2) MHR had moderate sensitivity and specificity to predict mixed and fatty plaques and 3) MHR was found to be a significant independent predictor for mixed and fatty plaques in patients with intermediate carotid artery disease, after adjusting for other risk factors in multivariate analysis.

Atherosclerosis is the main pathological finding in patients with ischemic heart disease and cerebrovascular disease (16). Fibrous cap and necrotic center are two layers of atherosclerotic plaque. Foam cells derived from macrophages are the main cellular component and cholesterol crystals are the main acellular component of the plaque. Monocytes and macrophages provoke atherosclerotic process via cytokine secretion and foam cell formation. Cytokines activate all stages of atherosclerosis, including onset, progression, rupture and thrombus formation (17). Total amount of inflammatory markers were found to have a predictive role for subsequent cardiovascular disease $(18,19)$. Moreover, monocyte count as a progenitor of foam cells was shown to be a predictor of new plaque formation (20).

High density lipoprotein, as an antiatherosclerotic molecule, reverses cholesterol transport from the plaque and inhibits activation, adhesion and infiltration of monocytes (8). Murphy et al. (7) postulated in their study that HDL exerted its effect through CD11b molecule on the surface of monocytes. CD11b is responsible for binding to endothelial cells and migrating from vascular wall.

Monocyte/high density lipoprotein ratio emerges as a combination of these two parameters and reflects the underlying inflammatory process. Previous studies demonstrated that MHR was useful for the diagnosis of subclinical carotid atherosclerosis in diabetics (21) and had a prognostic role for patients with coronary artery disease undergoing percutaneous coronary intervention (22).

Stenosis severity and plaque morphology were detected by CTA in this study. Calcified, mixed and fatty plaque morphology in asymptomatic patients with intermediate carotid stenosis were compared in terms of MHR. Previous studies reported calcified plaque constituted higher smooth muscle and lower intraplaque hemorrhages and fatty content. Hence, this plaque was very stable and was more frequently found in asymptomatic patients compared to patients who had ischemic cerebrovascular event (23). Increased risk of rupture and thromboembolism were demonstrated with fatty plaques in the same study (23). 
Another study by Ahmadi et al. (24) found an additional prognostic role of mixed and fatty plaques in symptomatic with nonobstructive coronary artery disease.

Identification of high risk individuals with intermediate carotid artery stenosis for developing symptoms is crucial. Morphological ultrastructure could give substantial information. Although there are studies comparing the morphological status of plaques causing asymptomatic intermediate carotid artery stenosis in terms of inflammatory parameters (22), no clinical study in the literature has evaluated the predictive value of MHR for this purpose. The relation between mixed and fatty plaques and novel inflammatory markers should be definitely set. Our study showed that MHR had a strong predictive role for mixed and fatty carotid plaques in the carotid artery. Taken together with close relationship of these plaques with other inflammatory markers reported in previous studies (25), mixed and fatty plaques are very unstable and put the patient at high risk category. Few patients were taking antiaggregant and statin in our study. Aggressive medical treatment including high dose statins and antiaggregants may be initiated earlier in asymptomatic intermediate carotid stenosis with mixed and fatty plaque morphology. Additionally, early invasive strategy could be taken into consideration for fatty plaques.

\section{Study Limitations}

Some limitations of our study are as follows. It was a single center study and performed in the small population. Serial MHR changes were not evaluated because we only measured MHR at baseline. Due to the lack of registration, no comparison was made between inflammatory marker levels such as C-reactive protein with MHR. Moreover, not all comorbidities and environmental factors that might affect inflammatory markers were taken into account.

\section{Conclusion}

Monocyte/high density lipoprotein ratio is a marker of inflammation and atherosclerosis. Increased MHR may be one of the factors associated with the presence of fatty and mixed carotid artery plaques that cause asymptomatic intermediate stenosis.

\section{Ethics}

Ethics Committee Approval: The study was approved by the local ethics committee with the number 3841 on 06.03.2020 and the study was conducted in accordance with ethical principles described by the Declaration of Helsinki.
Informed Consent: It is a retrospective study.

Peer-review: Externally peer-reviewed.

\section{Authorship Contributions}

Concept: A.E., Design: A.E., Data Collection or Processing: E.K., Analysis or Interpretation: E.K., Writing: A.E.

Conflict of Interest: No conflict of interest was declared by the authors.

Financial Disclosure: The authors declared that this study has received no financial support.

\section{References}

1. Gorelick PB, Wong KS, Bae HJ, Pandey DK. Large artery intracranial occlusive disease: a large worldwide burden but a relatively neglected frontier. Stroke 2008;39(8):2396-2399.

2. Cybulsky MI, Gimbrone MA Jr. Endothelial expression of a mononuclear leukocyte adhesion molecule during atherogenesis. Science 1991;251(4995):788-791.

3. Kolodgie FD, Burke AP, Farb A, Gold HK, Yuan J, Narula J, et al. The thin-cap fibroatheroma: A type of vulnerable plaque: The major precursor lesion to acute coronary syndromes. Curr Opin Cardiol 2001;16(5):285-292.

4. Hansson GK, Libby P, Schönbeck U, Yan ZQ. Innate and adaptive immunity in the pathogenesis of atherosclerosis. Circ Res 2002;91(4):281-291.

5. Kazmierski R, Guzik P, Ambrosius W, Ambrosius W, Ciesielska A, Moskal J, et al. Predictive value of white blood cell count on admission for in-hospital mortality in acute stroke patients. Clin Neurol Neurosurg 2004;107(1):38-43.

6. Olivares R, Ducimetière P, Claude JR. Monocyte count: a risk factor for coronary heart disease? Am J Epidemiol 1993;137(1):49-53.

7. Murphy AJ, Westerterp M, Yvan-Charvet L, Tall AR. Antiatherogenic mechanisms of high density lipoprotein: effects on myeloid cells. Biochim Biophys Acta 2012;1821(3):513-521.

8. Hafiane A, Genest J. High density lipoproteins: measurement techniques and potential biomarkers of cardiovascular risk. BBA Clin 2015;3:175-188.

9. Prospective Studies Collaboration; Lewington S, Whitlock G, Clarke R, Sherliker P, Emberson J, Halsey J, et al. Blood cholesterol and vascular mortality by age, sex, and blood pressure: a metaanalysis of individual data from 61 prospective studies with 55,000 vascular deaths. Lancet 2007;370(9602):1829-1839.

10. Canpolat U, Çetin EH, Cetin S, Aydin S, Akboga MK, Yayla C, et al. Association of Monocyte-to-HDL cholesterol ratio with slow coronary flow is linked to systemic inflammation. Clin Appl Thromb Hemost 2016;22(5):476-482.

11. Bolayir A, Gokce SF, Cigdem B, Bolayir HA, Yildiz OK, Bolayir E, et al. Monocyte/high-density lipoprotein ratio predicts the mortality in ischemic stroke patients. Neurol Neurochir Pol 2018;52(2):150155.

12. Wang PQ, Wang Y, Zhang GB, Zhou PY, Liu JZ, Wang SA. Study on the carotid atherosclerotic plaque of patients suffering from ischemic cerebrovascular disease by 64 slices CT. Eur Rev Med Pharmacol Sci 2015;19(18):3480-3485. 
13. Wintermark M, Jawadi SS, Rapp JH, Tihan T, Tong E, Glidden DV, et al. High-resolution CT imaging of carotid artery atherosclerotic plaques. AJNR Am J Neuroradiol 2008;29(5):875-882.

14. Liapis CD, Bell PR, Mikhailidis D, Sivenius J, Nicolaides A, e Fernandes JF, et al. ESVS guidelines. Invasive treatment for carotid stenosis: indications, techniques. Eur J Vasc Endovasc Surg 2009;37(4 Suppl):1-19.

15. Brott TG, Halperin JL, Abbara S, Bacharach JM, Barr JD, Bush RL, et al. 2011 ASA/ACCF/AHA/AANN/AANS/ACR/ASNR/CNS/ SAIP/SCAI/SIR/SNIS/SVM/SVS guideline on the management of patients with extracranial carotid and vertebral artery disease: executive summary: a report of the American College of Cardiology Foundation/American Heart Association Task Force on Practice Guidelines, and the American Stroke Association, American Association of Neuroscience Nurses, American Association of Neurological Surgeons, American College of Radiology, American Society of Neuroradiology, Congress of Neurological Surgeons, Society of Atherosclerosis Imaging and Prevention, Society for Cardiovascular Angiography and Interventions, Society of Interventional Radiology, Society of NeuroInterventional Surgery, Society for Vascular Medicine, and Society for Vascular Surgery. Circulation 2011;124(4):489-532.

16. Mathers CD, Boerma T, Ma Fat D. Global and regional causes of death. Br Med Bull 2009;92:7-32.

17. Libby P. Inflammation in atherosclerosis. Arterioscler Thromb Vasc Biol 2012;32(9):2045-2051.

18. Ridker PM, Hennekens CH, Buring JE, Rifai N. C-reactive protein and other markers of inflammation in the prediction of cardiovascular disease in women. N Engl J Med 2000;342(12):836843.
19. Köklü E, Yüksel İÖ, Arslan Ş, Bayar N, Çağırcı G, Gencer ES. Is elevated neutrophil-to-lymphocyte ratio a predictor of stroke in patients with intermediate carotid artery stenosis? J Stroke Cerebrovasc Dis 2016 Mar;25(3):578-584.

20. Gratchev A, Sobenin I, Orekhov A, Kzhyshkowska J. Monocytes as a diagnostic marker of cardiovascular diseases. Immunobiology 2012;217(5):476-482.

21. Chen JW, Li C, Liu ZH, Shen Y, Ding FH, Shu XY, et al. The role of monocyte to high-density lipoprotein cholesterol ratio in prediction of carotid intima-media thickness in patients with type 2 diabetes. Front Endocrinol (Lausanne) 2019;10:191.

22. Wu TT, Zheng YY, Chen Y, Yu ZX, Ma YT, Xie X. Monocyte to highdensity lipoprotein cholesterol ratio as long-term prognostic marker in patients with coronary artery disease undergoing percutaneous coronary intervention. Lipids Health Dis 2019;18(1):180.

23. van Lammeren GW, den Hartog AG, Pasterkamp G, Vink A, de Vries JPPM, de Borst GJ. Asymptomatic carotid artery stenosis: identification of subgroups with different underlying plaque characteristics. Eur J Vasc Endovasc Surg 2012;43(6):632-636.

24. Ahmadi N, Nabavi V, Hajsadeghi F, Flores F, French WJ, Mao SS, et al. Mortality incidence of patients with non obstructive coronary artery disease diagnosed by computed tomography angiography. Am J Cardiol 2011;107(1):10-16.

25. Yüksel İÖ, Köklü E, Arslan Ş, Çağırcı G, Göksu EÖ, Koç P, et al. Association of Neutrophil/Lymphocyte Ratio with Plaque Morphology in Patients with Asymptomatic Intermediate Carotid Artery Stenosis. Korean Circ J 2016;46(5):699-705. 